\title{
PROFIL HEMOSIT UDANG PISANG (Penaeus Sp.) YANG TERSERANG EKTOPARASIT PADA TAMBAK DI PANTAI BARAT ACEH
}

\section{THE HAEMOCYTE PROFIL OF PISANG SHRIMP (Penaeus Sp.) INFECTED BY ECTOPARASITES FROM BRACKISH WATER PONDS IN WEST ACEH COAST}

\author{
Fitria Rahmayanti ${ }^{1}$, Neneng Marlian ${ }^{2}$ \\ ${ }^{1}$ Program Studi Akuakultur, Fakultas Perikanan dan Ilmu Kelautan \\ Universitas Teuku Umar \\ ${ }^{2}$ Program Studi Sumber Daya Akuatik, Fakultas Perikanan dan Ilmu Kelautan \\ Universitas Teuku Umar \\ Korespondensi: fitriarahmayanti@utu.ac.id
}

\begin{abstract}
Abstrak
Udang Penaeid merupakan salah satu komoditas perairan yang dibudidayakan dan diminati oleh masyarakat saat ini. Udang Pisang (Penaeus sp.) adalah salah satu udang yang termasuk ke dalam Genus Penaeus yang hanya dapat dijumpai di wilayah Pantai Barat Aceh dan mulai dibudidayakan. Kegiatan budidaya tersebut tidak terlepas dari infeksi parasit, baik endoparasit maupun ektoparasit. Penelitian ini dilaksanakan pada bulan Mei sampai dengan Agustus 2018 dan bertujuan untuk mengetahui profil hemosit Udang Pisang (Penaeus sp.) yang dibudidayakan pada tambak di Pantai Barat Aceh ditinjau dari serangan ektoparasit dan parameter kualitas airnya. Hasil penelitian menunjukkan Total Haemocyte Count (THC) rata-rata Udang Pisang (Penaeus sp.) dari Kabupaten Aceh Besar, Aceh Jaya, Aceh Barat dan Nagan Raya berkisar antara 3.97- $4.90 \times 10^{7} \mathrm{sel} / \mathrm{ml}$. Jenis ektoparasit yang menyerang Udang Pisang (Penaeus sp.) adalah Vorticella sp., Epistylis sp., dan Zoothamnium sp. Parameter kualitas air yang diukur selama penelitian menunjukkan kisaran DO $3.98-4.27 \mathrm{mg} / \mathrm{L}$, suhu $33.2-35.7^{\circ} \mathrm{C}, \mathrm{pH} 7-7.6$, dan salinitas $22.4-26 \mathrm{ppt}$.
\end{abstract}

Kata kunci: Udang Pisang, ektoparasit, Total Haemocyte Count (THC), Pantai Barat Aceh.

\begin{abstract}
Penaeid Shrimp is one of the aquatic commodities that are cultivated. Pisang Shrimp (Penaeus sp.) is one of the shrimp included to Genus Penaeus which can only be found in Aceh West Coast and began to be cultivated. Cultivation activities are not separated from parasitic infections, including endoparasites and ectoparasites. This study was conducted in May to August 2018 and aims to determine the hemocyte profile of Pisang Shrimp (Penaeus sp.) are cultivated in West Aceh Coast in terms of ectoparasite infection and water quality parameters. The results showed that the average of Total Haemocyte Count (THC) of Pisang Shrimp (Penaeus sp.) collected from Aceh Besar, Aceh Jaya, Aceh Barat and Nagan Raya Regency ranged between 3.97 to $4.90 \times 10^{7}$ cells $/ \mathrm{ml}$. The ectoparasites that infected Pisang Shrimp (Penaeus sp.) are Vorticella sp., Epistylis sp., and Zoothamnium sp. Water quality parameters measured during the study showed the range of DO were $3.98-4.27 \mathrm{mg} / \mathrm{L}$, temperature were $33.2-35.7^{\circ} \mathrm{C}$, $\mathrm{pH}$ were $7-7.6$, and salinity were 22.4 26 ppt.
\end{abstract}

Keywords: Pisang Shrimp, ectoparasites, Total Haemocyte Count (THC), West Aceh Coast.

\footnotetext{
${ }^{1}$ Fakultas Perikanan dan Ilmu Kelautan, Universitas Teuku Umar Korespondensi: Jurusan Akuakultur, Fakultas Perikanan dan Ilmu Kelautan, Universitas Teuku Umar, Kampus UTU Meulaboh, Alue Peunyareng 23615, Telp: +62 85297805010, email: fitriarahmayanti@utu.ac.id
} 


\section{PENDAHULUAN}

Saat ini udang budidaya adalah komoditi yang dikembangkan dalam bidang akuakultur serta menjadi kekuatan utama dalam peningkatan perdagangan produk perikanan secara internasional. Pasar utama udang adalah Jepang, Amerika Serikat dan Uni Eropa (UE), dan eksportir terbesar dari udang tambak adalah Thailand, Ekuador, Indonesia, India, Meksiko, Bangladesh, dan Vietnam. Permintaan udang diperkirakan akan meningkat di tahun mendatang (FAO, 2012).

Udang Pisang (Penaeus sp.) adalah udang lokal yang terdapat di wilayah Pantai Barat Aceh, udang tersebut memiliki ciri morfologis yang hampir sama dengan Udang Windu (Penaeus monodon). Udang Pisang memiliki kemiripan dengan Udang Windu dari sisi morfologi dan tingkah laku. Penyebaran Udang Pisang (Penaeus sp.) meliputi perairan Pantai Barat Selatan Aceh. Menurut pengalaman lapangan beberapa tambak udang di Aceh, udang pisang dapat dipelihara pada kepadatan yang lebih tinggi >30 ekor/m2 (Sarifuddin et al., 2014). Sebagian besar produksi Udang Pisang di Aceh bergantung pada tangkapan nelayan. Kini budidaya Udang Pisang mulai dikembangkan khususnya di wilayah Kabupaten Aceh Jaya dan Aceh Besar. Usaha budidaya Udang Pisang yang mulai dikembangkan ini sebagian besar menggunakan benih yang berasal dari alam dan sebagian kecil dari tempat pembenihan.

Usaha budidaya tentu saja tidak terlepas dari permasalahan penyakit yang menyerang komoditas budidaya. Menurut Aziz et al. (2011), salah satu penyebab penyakit pada udang adalah ektoparasit. Suwarsito dan Mustafidah (2011) menyatakan bahwa gangguan terhadap budidaya dapat disebabkan oleh pathogen, pakan maupun kualitas air yang kurang menunjang kehidupan budidaya.

Kualitas air pada budidaya udang bergantung pada sistem budidaya yang diterapkan. Selain itu, perkembangan terhadap budidaya udang juga berpotensi terhadap penyebaran penyakit. Menurut Elfrida et al. (2012), pemberian pakan dengan jumlah yang tinggi akan mengakibatkan sisa pakan mengendap dan dalam waktu yang lama akan menumpuk dan terakumulasi dengan bahan organik yang berasal dari berbagai proses kimia yang terjadi dalam perairan.

Tambak sebagai habitat komoditi yang dibudidayakan memiliki peranan penting dalam usaha peningkatan produksi. Parameter kualitas air yang menurun dapat mempengaruhi respon imun pada udang sehingga menyebabkan udang mudah terserang penyakit. Menurut Yuniasari (2009), penurunan kualitas air dapat menjadi stressor bagi munculnya berbagai jenis penyakit pada udang. Selanjutnya, Saha et al. (2010) mengungkapkan bahwa udang merupakan kelompok Crustacea yang memiliki sel hemosit sebagai imuno effectors blood cells yang menunjukkan fungsi fisiologis dan respon imun.

Krustase tidak memiliki respon imune spesifik (adaptive) dan nampak bergantung pada berbagai respon imun nonspesifik (innate). Meskipun dianggap tidak begitu memuaskan, respon imun nonspesifik mampu dengan cepat dan efisien mengenal dan menghancurkan material asing, termasuk patogen (Vargas-Albores \& Yepiz- Plascencia 2000; Witteveldt et al., 2003). Hemosit krustase, dan invertebrata lain, memainkan peranan penting dalam sistem pertahanan tubuh terhadap patogen seperti virus, bakteri, fungi, protozoa, dan metazoa (Johansson et al., 2000; Sindermann, 1990; Rodriquez \& Le Moullac, 2000). Jumlah hemosit dapat sangat bervariasi berdasarkan spesies, respon terhadap infeksi, stres lingkungan, aktivitas endokrin selama siklus molting (Johansson et al., 2000). Perhitungan sel hemosit dan aktifitas fagositosis menunjukkan informasi fisiologis efek sub akut pada krustasea dan 
dapat dijadikan sebagai indikator untk mengetahui respon fisiologis krustasea akibat stressor (Lorenzon et al., 2001).

Penelitian ini bertujuan untuk mengetahui profil hemosit Udang Pisang (Penaeus sp.) pada tambak di Pantai Barat Aceh ditinjau dari infeksi ektoparasit dan parameter kualitas airnya. Hasil dari penelitian ini diharapkan dapat dijadikan gambaran kesehatan udang pisang yang dibudidayakan dan kaitannya dengan parameter kualitas air pada media budidaya, sehingga didapatkan jalan keluar dari permasalahan budidaya yang terjadi selama ini.

\section{METODE PENELITIAN}

Waktu dan Tempat Penelitian

Penelitian ini dilaksanakan dari bulan Mei sampai dengan Agustus 2018. Sampel diambil pada tambak budidaya Udang Pisang di empat kabupaten, yaitu Kabupaten Aceh Besar, Aceh Jaya, Aceh Barat dan Nagan Raya.

\section{Bahan dan Alat}

Bahan yang digunakan pada penelitian ini adalah Udang Pisang (Penaeus sp.), antikoagulan Na-sitrat 3.8\%, dan Tripan Blue Stain Solution. Sedangkan alat yang digunakan adalah jarum suntik 23G ukuran 1 $\mathrm{ml}$, haemocytometer, mikroskop, Cover glass, glass slide, vial, wadah plastik, handtally counter, DO meter, $\mathrm{pH}$ meter, thermometer dan refractometer.

Prosedur Penelitian

\section{Sampling}

Pengambilan sampel dilakukan secara acak sebanyak 20 ekor pada setiap lokasi. Pengambilan sampel dengan menggunakan alat tangkap berupa jala. Sampel yang diambil dari tambak dalam keadaan hidup langsung dimasukkan ke dalam plastik yang berisi air dan oksigen.
Pengambilan dan Pengamatan Haemolymph Udang Pisang (Penaeus sp.)

Haemolymph diambil sebanyak $0.1 \mathrm{ml}$ dari pangkal kaki renang pertama dengan syringe $1 \mathrm{ml}$ yang sudah berisi $0.1 \mathrm{ml}$ antikoagulan Na-sitrat $3.8 \%$. Kemudian dimasukkan kedalam tabung vial yang telah berisi Tripan Blue Stain Solution campuran dihomogenkan dengan cara menggoyangkan tangan membentuk angka 8 . Tetesan pertama dibuang, selanjutnya diteteskan ke haemocytometer. Jumlah sel dihitung per $\mathrm{ml}$ dibawah mikroskop dengan pembesaran 400 kali.

\section{Perhitungan Total Haemocyte Count (THC) Penghitungan THC dilakukan menggunakan haemocytometer dengan prosedur (Courdova et al., 2002) sebagai berikut:

$$
\mathrm{THC}=\frac{\text { Jumlah sel }}{\text { Volume }} \times \text { Pengenceran } 10^{6} \mathrm{sel} / \mathrm{ml}
$$

Pengamatan Ektoparasit

Identifikasi ektoparasit yang dilakukan yaitu pemeriksaan organ luar yang dilakukan di Labotarium MIPA Terpadu Universitas Teuku Umar.

Parameter kualitas air tambak diambil saat pengambilan sampel udang pisang (Penaeus sp.). Adapun parameter yang diambil adalah Dissolved Oxygen (DO), salinitas, $\mathrm{pH}$, dan suhu.

\section{HASIL DAN PEMBAHASAN}

\section{Total Haemocyte Count (THC)}

Hasil perhitungan Total Haemocyte Count (THC) rata-rata Udang Pisang (Penaeus sp.) untuk keempat kabupaten di Pantai Barat Aceh berkisar antara 3.97- $4.90 \mathrm{x}$ $10^{7} \mathrm{sel} / \mathrm{ml}$. 
Tabel 1. Total Haemocyte Count (THC) Udang Pisang (Penaeus sp.) yang Terserang Ektoparasit di Tambak Pantai Barat Aceh

\begin{tabular}{ccc}
\hline Kabupaten & $\begin{array}{c}\text { Jumlah THC } \\
\text { Udang Pisang } \\
(\text { sel/ml) }\end{array}$ & $\begin{array}{c}\text { THC Rata- } \\
\text { Rata (sel/ml) }\end{array}$ \\
\hline Aceh Besar & $698 \times 10^{6}$ & $4.65 \times 10^{7}$ \\
Aceh Jaya & $784 \times 10^{6}$ & $4.90 \times 10^{7}$ \\
Aceh Barat & $674 \times 10^{6}$ & $3.97 \times 10^{7}$ \\
Nagan Raya & $814 \times 10^{6}$ & $4.52 \times 10^{7}$ \\
\hline
\end{tabular}

Kelimpahan jumlah dan jenis sel hemosit pada krustasea dapat bervariasi. Hal tersebut dipengaruhi oleh berbagai hal antara lain jenis kelamin, temperatur air, siklus moulting, kondisi kelaparan (Yildiz dan Atar, 2002). Pengumpulan sampel Udang Pisang dilakukan pada musim panas dimana suhu meningkat (Tabel 2) sehingga menyebabkan udang stress dan rentan terhadap serangan parasit. Akibatnya, Total Haemocyte Count (THC) udang cenderung mengalami penurunan dikarenakan efek stress.

Berdasarkan hasil pengamatan dan perhitungan THC, nilai THC Udang Pisang di Kabupaten Aceh Barat adalah yang terendah. Hal ini diduga karena kualitas air yang rendah dibandingkan tiga kabupaten lain, seperti yang terlihat pada Table 2.

\section{Ektoparasit pada Udang Pisang (Penaeus sp.)}

Hasil penelitian didapatkan tiga jenis ektoparasit yang menyerang Udang Pisang yang dibudidayakan pada tambak di masingmasing kabupaten yang ada di sepanjang Pantai Barat Aceh yaitu Zoothamnium sp., Epistyles sp. dan Vorticella sp. Ketiga ektoparasit tersebut termasuk ke dalam filum Protozoa. Menurut Bastiawan et al. (1991), kelompok protozoa ini umumnya dijumpai pada kondisi tambak banyak mengandung sisa bahan organik dan mutu air yang buruk.

Menurut Irvansyah (2012), Vorticella sp. berwarna kekuningan atau kehijauan, tangkai pipih dan silindris dengan zooid berbentuk seperti lonceng terbalik.
Setyaningsih et al. (2014) menyatakan bahwa Vorticella sp. berbentuk seperti lonceng, putih transparan dengan tangkai panjang dan tidak berkoloni, memiliki contracted cell, yang dapat berkontraksi dengan memanjangkan dan memendekkan bagian tangkainya.

Epistylis sp. juga berbentuk lonceng dan berwarna transparan, berkoloni antara 2-5 individu. Memiliki flagella, makronukleus, infundibulum dan contracted cell (Setyaningsih et al., 2014). Epistylis sp. banyak ditemukan pada kondisi oksigen terlarut rendah, bergerombol seperti benang yang tumbuh dan menyerang bagian tubuh kepiting yang menyebabkan stress, gangguan pergerakan dan respirasi hingga kematian (Jithendran et al., 2010).

Zoothamnium sp. merupakan protozoa kelas ciliata yang hidup berkoloni, berwarna keputihan dan menempel pada substrat dengan menggunakan batang (pedicle) yang bercabang (Murtidjo, 2003). Menurut Mahasari et al. (2016), Udang Windu yang terinfeksi parasit akan mengalami peningkatan jumlah zooid hingga menyebabkan perubahan warna tubuh hingga berwarna coklat tua.

Udang Pisang yang berasal dari tambak di keempat kabupaten yang dijadikan titik lokasi pengambilan sampel terinfeksi jenis ektoparasit yang sama. Diduga hal ini terjadi karena semua lokasi tambak yang dijadikan sebagai titik pengambilan sampel merupakan tambak tanah dan menggunakan sistem budidaya tradisional ekstensif dimana kualitas air tidak terkontrol dengan baik.

Menurut Wiharyanto (2011), pola budidaya ekstensif merupakan tipe tambak tanpa aerasi, dimana sumber air mengandalkan pasang surut air laut. Mahasri et al. (2008) menyatakan bahwa kelas ciliata seperti Zoothamnium sp., Epistylis sp. dan Vorticella sp. dapat hidup normal pada kualitas air yang baik, akan tetapi protozoa tersebut akan meningkat populasinya pada perairan dengan kualitas air yang rendah. 
Parameter Kualitas Air

Pengukuran parameter kualitas air dilakukan pada saat pengambilan sampel Udang Pisang (Penaeus sp.) yang akan diamati ektoparasit dan profil hemositnya. Adapun parameter kualitas air yang diukur adalah suhu, Dissolved Oxygen (DO), pH dan salinitas.

Tabel 2. Parameter Kualitas Air Tambak Selama Penelitian

\begin{tabular}{|l|c|c|c|c|}
\hline \multirow{3}{*}{ Kabupaten } & \multicolumn{4}{|c|}{ Parameter } \\
\cline { 2 - 5 } & $\begin{array}{c}\text { Suhu } \\
\left({ }^{\circ} \mathrm{C}\right)\end{array}$ & $\begin{array}{c}\text { DO } \\
(\mathrm{mg} / \mathrm{L})\end{array}$ & $\mathrm{pH}$ & $\begin{array}{c}\text { Salinitas } \\
(\mathrm{ppt})\end{array}$ \\
\hline Aceh Besar & 33.8 & 4.15 & 7.6 & 22.4 \\
\hline Aceh Jaya & 34.2 & 4.27 & 7.3 & 26 \\
\hline Aceh Barat & 35.7 & 3.98 & 7 & 23.2 \\
\hline Nagan Raya & 33.2 & 4.09 & 7.3 & 25.6 \\
\hline
\end{tabular}

Hasil pengukuran parameter kualitas air selama penelitian menunjukkan masih dalam batas normal. Menurut Buwono (1993), batas minimum oksigen terlarut untuk budidaya udang adalah $3 \mathrm{mg} / \mathrm{L}$ dan salinitasnya berkisar antara 15-25 ppt untuk pertumbuhan yang optimum. Kualitas air sangat mempengaruhi serangan ektoparasit dan Total Haemocyte Count (THC) pada kelompok krustasea.

Anshary (2008), menyatakan bahwa parasite yang termasuk kelompok protozoa biasanya dijumpai pada udang yang stres dan dipengaruhi oleh perubahan fluktuasi kondisi kualitas air terutama suhu, juga wadah pemeliharaan yang banyak mengandung sisasisa pakan sehingga terjadi penumpukan bahan organik yang akan meningkatkan kadar amoniak serta menyebabkan turunnya kandungan oksigen terlarut diperairan.

Kadar DO dari ketiga kabupaten menunjukkan nilai yang tidak terlalu jauh berbeda, hanya saja, di Kabupaten Aceh Barat, kadar DO berada pada $3.98 \mathrm{mg} / \mathrm{L}$. Hal ini diduga dipengaruhi oleh lokasi tambak yang dekat dengan sumber limbah rumah tangga. Selain itu, suhu selama penelitian tergolong tinggi yaitu berkisar antara 33.2$35.7^{\circ} \mathrm{C}$. Keadaan ini akan meningkatkan kemungkinan terjadinya serangan parasit pada krustasea. Menurut Jayakumar dan Ramasarny (1999), hambatan pertukaran oksigen menyebabkan kondisi hipoksia hingga dapat memicu kematian krustasea Penaeus indicus.

\section{KESIMPULAN}

1. Profil hemosit Udang Pisang (Penaeus sp.) yang terserang ektoparasit di tambak Pantai Barat Aceh menunjukkan Total Haemocyte Count (THC) berkisar antara 3.97- $4.90 \times 10^{7} \mathrm{sel} / \mathrm{ml}$.

2. Jenis ektoparasit yang menyerang Udang Pisang (Penaeus sp.) di tambak Pantai Barat Aceh adalah Vorticella sp., Epistylis sp., dan Zoothamnium sp.

3. Kondisi kualitas air yang buruk, seperti DO yang rendah dan suhu yang tinggi dapat meningkatkan serangan ektoparasit pada Udang Pisang (Penaeus sp.) dan dapat mempengaruhi hemosit sebagai respon stres terhadap kondisi lingkungan yang buruk.

\section{DAFTAR PUSTAKA}

Aziz, H. Iromo dan Darto. 2011. Identifikasi Ektoparasit pada Udang Windu (Penaeus monodon fabricus) di Tambak Tradisional Kota Tarakan. Fakultas Perikanan Ilmu Kelautan. Universitas Borneo.

Bastiawan. D., A. Rukyani, P. Taufik, dan A. Purnomo. 1991. Penanggulangan Hama dan Penyakit pada Usaha Ikan dan Udang. Puslitbang Perikanan, Badan Litbang Pertanian, Departemen Pertanian.

Courdova, A. I. C., Saavedra, N. H., Phillipis, R. D., dan Ascentio, F. 2002. Generation of Superoxide Anion and SOD Activity in Haemocytes and Muscle of American White Shrimp (Litopenaeus vannamei) as a response to $\beta$-glucan and Respiratory Burst 
Activity of Turbot Phagocytes. Fish and Shellfish Immunology. 12: 353-366.

Elfrida, L., Deswati dan B. Fitri. 2012. Pemanfaatan Sedimen KJA Danau Maninjau untuk Memproduksi Chlorella sp. Prosiding Seminar Nasional Limnologi VI. Universitas Bung Hatta.

Irvansyah. M.Y., Abdulgani N., Mahasari G. 2012. Identifikasi dan intensitas ektoparasit pada kepiting bakau (Scylla serrata) stadia kepiting muda di pertambakan kepiting, Kecamatan Sedati, Kabupaten Sidoarjo. Jurnal Sains dan Seni ITS.

Jayakumar, R., \& Ramasamy, P. (1999). Bacterial and protozoan (Ciliate) diseases of prawn Penaeus indicus (Decapoda: Crustacea). Indian Journal of Marine Sciences. 28(3): 285-296.

Jithendran, K. P., Poornima, M., Balasubramanian, C. P., dan Kulasekarapandian, S. 2010. Diseases of Mud Crabs (Scylla spp.): an overview. Indian Journal of Fisheries. 57(3): 55-63.

Lorenzon, S., Francese, M., Smith, V. J., \& Ferrero, E. A. 2001. Heavy metals affect the circulating haemocyte number in the shrimp Palaemon elegans. Fish and Shellfish Immunology. 11(6): 459-465.

Mahasri, G., L. Raya, A. S. Mubarak dan B. Irawan. 2008. Gambaran Patologi Insang dan Kulit Udang Windu (Penaeus monodon Fab.) yang Terserang Ciliata Patogen dari Famili Vorticellidae (Zoothamnium sp.). Berkala Ilmiah Perikanan, 3 (1) : 95103.

Mahasri, G., A. Heryamin., Kismiyati. 2016. Prevalensi ektoparasit pada udang vanname (Litopenaeus vannamei) dengan padat tebar yang berbeda di tempat penggelondongan di Kabupaten Gresik. Journal of Aquaculture and Fish Health. 5(2): 7-13.
Murtidjo, B. A. 2003. Benih Udang Windu Skala Kecil. Kanisius. Yogyakarta.

Saha, S., Ray, M., \& Ray, S. 2010. Shift in Cytoarchitecture of Immunocytes of Mudcrab Exposed to Arsenic. International Journal of Applied Biology and Pharmaceutical Technology 1(2): 234-246.

Sarifuddin., S. Ibnu., F. Irvan., P. Widya., Syafrizal, Jalaluddin., R. Teuku., Nurbariah. 2014. Petunjuk Teknis Pembenihan Udang Pisang. Balai Pengembangan Budidaya Air Payau Ujung Batee, Ujung Batee.

Setiyaningsih, L., Sarjito, \& Haditomo, A. H. C. 20014. Identifikasi Ektoparasit pada Kepiting Bakau (Scylla serrata) yang Dibudidayakan di Tambak Pesisir Pemalang. Journal of Aquaculture Management and Technology. 3(3): 816.

Wiharyanto, D. 2011. Budidaya Udang Windu Tanpa Pakan dan Tanpa Aerasi. WWF Indonesia.

Yildiz, H. Y., \& Atar, H. H. (2002). Haemocyte Classification and Differential Counts in the Freshwater Crab, Potamon fluviatilis. Turkish Journal of Veterinary and Animal Sciences. 26(2): 403-406. 